\title{
Immuno-PET of Cancer: A Revival of Antibody Imaging
}

$\mathbf{W}$ ith the identification of tumorassociated antigens more than $30 \mathrm{y}$ ago and the development of hybridoma technology in 1975, investigators realized that Paul Ehrlich's vision to effectively target drugs to diseased tissues could be tested. It was shown that monoclonal antibodies could specifically target tumors $(1,2)$, and it was hypothesized that cancer could be treated with naked antibodies by inducing antibody-dependent cellular cytotoxicity, complement-dependent cytotoxicity, or apoptosis or with antibodies tagged with cytotoxic drugs or radionuclides. Indeed, in the early

\section{See page 1173}

1980s, clinical studies provided the proof of principle that tumors could be visualized using radiolabeled antibodies. As a result, a few labeled antibody products were marketed for scintigraphic imaging of tumors: satumomab pendetide (OncoScint; Cytogen Corp.) for colorectal and ovarian carcinoma, arcitumomab (CEA scan) for colorectal cancers, nofetumomab merpetan (Verluma; BoehringerIngelheim Pharma KG) for small cell lung carcinoma, and capromab pentetide (ProstaScint; EUSA Pharma) for prostate cancer. However, the diagnostic accuracy of these antibody-based scans was limited, and when ${ }^{18}$ F-FDG PET was introduced in the clinic, antibodybased imaging for staging and restaging

Received Mar. 18, 2011; revision accepted Apr. 4, 2011.

For correspondence or reprints contact: Otto C. Boerman, Department of Nuclear Medicine, Radboud University Nijmegen Medical Centre, P.O. Box 9101, 6500 HB Nijmegen, The Netherlands.

E-mail: o.boerman@nucmed.umcn.nl COPYRIGHT @ 2011 by the Society of Nuclear Medicine, Inc.

DOI: 10.2967/jnumed.111.089771 of cancer patients became obsolete. In most groups of cancer patients, the sensitivity and specificity of ${ }^{18} \mathrm{~F}-\mathrm{FDG}$ PET was superior and the resolution of the images was higher. Moreover, quantitative analysis of the images provided valuable information about tumor metabolism and response to therapy.

In this issue of The Journal of Nuclear Medicine, Carrasquillo et al. at Memorial Sloan-Kettering Cancer Center report their observations after injection of the humanized A33 monoclonal antibody labeled with ${ }^{124} \mathrm{I}$ in 25 patients with colorectal cancer (3). Clearly, during the last few years a revival of imaging with radiolabeled antibodies due to the application of PET has taken place. Because accumulation of antibodies in tumors is a slow process, as is their clearance from the blood (half-time $\left[\mathrm{T}_{1 / 2}\right]=$ 50-90 h), immuno-PET uses antibodies that are labeled with positron-emitting radionuclides with a relatively long half-life, such as ${ }^{124} \mathrm{I}\left(\mathrm{T}_{1 / 2}=\right.$ $100 \mathrm{~h})$ and ${ }^{89} \mathrm{Zr}\left(\mathrm{T}_{1 / 2}=78 \mathrm{~h}\right)$.

Carrasquillo et al. reported that 9 of 12 primary tumors and most liver metastases in these patients were visualized with ${ }^{124}$ I-labeled huA33, with a median tumor-to-background ratio of 4:1 (3), which is comparable to the results of previous imaging studies when the same antibody was labeled with ${ }^{131} \mathrm{I}(4,5)$. Obviously, the resolution of the ${ }^{124} \mathrm{I}$ images is better than the resolution of the ${ }^{131} \mathrm{I}$ images, but this improvement will only marginally improve the diagnostic accuracy of the images, as accuracy is determined mainly by the target-tobackground ratios. On the other hand, immuno-PET of cancer can be clinically relevant by adding specificity when undetermined masses are evaluated, as has been shown by the same group of investigators in patients suspected of renal cell carcinoma who were scheduled to undergo nephrectomy. Fifteen of the 16 patients with clear cell renal cancer showed accumulation of the ${ }^{124}$ I-labeled anti-carbonic anhydrase IX antibody in their primary tumor. None of the 9 patients with other renal masses showed any such accumulation (6). This study indicated that immuno-PET might be helpful in clinical decision making and might aid in the surgical management of small renal masses scheduled for partial nephrectomy. These promising results formed the basis for a recently completed multicenter phase III registration trial in 226 patients (7). Although publication of the full data is pending and approval has not yet been granted by the Food and Drug Administration, first communications of the results seem favorable (8).

Still, immuno-PET has important advantages over conventional radioimmunoscintigraphy. Immuno-PET provides not only higher-resolution images but also the concentration of the radiolabeled antibody in tissues of interest could be derived accurately from the images. In their report, Carrasquillo et al. elegantly validated this statement by demonstrating that the pharmacokinetics and tissue concentrations derived from the PET images were essentially the same as derived from the ex vivo measurements of blood and tissue samples in a $\gamma$-counter (3). This advantage could be exploited especially in myeloablative radioimmunotherapy to determine the maximum dose of activity that can safely be administered based on estimates of radiation doses to doselimiting organs. It has been shown that radiation doses of radioimmunotherapy with ${ }^{90}$ Y-ibritumomab tiuxetan (Zevalin; Spectrum Pharmaceuticals) can be predicted by immuno-PET with ${ }^{89} \mathrm{Zr}$-ibritumomab tiuxetan (9). The same group showed that this dose prediction also applies to radioimmunotherapy with 
${ }^{177} \mathrm{Lu}$ - and ${ }^{90}$ Y-labeled antibodies. However, for radioimmunotherapy with internalizing antibodies, the radiation dose to the bone marrow will be overestimated if based on ${ }^{89} \mathrm{Zr}$-dosimetry (10).

Immuno-PET could also be applied to quantitatively estimate expression of accessible antigens in the target tissue. Potentially, this application could lead to patient stratification of antibodybased therapies such as trastuzumab therapy in breast cancer patients. In current clinical practice, patients with metastasized breast cancer are eligible to be treated with trastuzumab if overexpression of the HER2 receptor in a tumor sample can be shown immunohistochemically or by in situ hybridization. It could be argued that this patient stratification can be done more accurately on the basis of immunoPET, because ${ }^{89} \mathrm{Zr}$-trastuzumab imaging can show actual targeting of cancer lesions in vivo (11).

Another important application of immuno-PET could be its use in the development of antibody-based drugs. PET of the ${ }^{124} \mathrm{I}$ - or ${ }^{89} \mathrm{Zr}$-labeled antibody drug in patients could provide useful quantitative information about pharmacokinetics, accumulation in targeted and nontargeted tissues, and saturation of the target antigen. Accurate dosing of a newly developed antibody could be based on immuno-PET studies, possibly speeding the development of antibody-based drugs. When analyzing the results of these studies, one should realize that immuno-PET shows the in vivo distribution of the radionuclide and that, when the radiolabeled antibody is metabolized in vivo, this distribution does not necessarily represent the immunoreactive antibody. This consideration is particularly relevant for internalizing antibodies: when the target cell internalizes the radiolabeled antibody, the antibody is catabolized in the lysosomes and the radiolabeled metabolite will either be released from the cell (e.g., ${ }^{124}$ I-labeled tyrosine) or residualize in the cell (e.g., ${ }^{89} \mathrm{Zr}$-desferal-lysine).

It appears that immuno-PET is just the beginning of a series of new technologic developments. New antibody formats, such as single-chain antibodies, diabodies, Nanobodies (Ablynx), and minibodies have now been labeled with positron emitters, allowing rapid imaging with high contrast (12). Affibody molecules, 7-kDa scaffolds derived from protein A with high affinity for HER2, epidermal growth factor receptor, and other tumor targets have now been labeled with ${ }^{68} \mathrm{Ga}$ and ${ }^{18} \mathrm{~F}$ (13) and can be used to determine receptor expression in cancer patients (14). Because of the rapid pharmacokinetics for immuno-PET with these constructs, shorter-lived positron emitters are used: ${ }^{68} \mathrm{Ga}\left(\mathrm{T}_{1 / 2}=1 \mathrm{~h}\right)$, ${ }^{18} \mathrm{~F}\left(\mathrm{~T}_{1 / 2}=2 \mathrm{~h}\right),{ }^{64} \mathrm{Cu}\left(\mathrm{T}_{1 / 2}=13 \mathrm{~h}\right)$, and ${ }^{76} \mathrm{Br}\left(\mathrm{T}_{1 / 2}=16 \mathrm{~h}\right)$.

Tumor-to-background ratios in antibody imaging can be improved by using pretargeting approaches. The tumor is pretargeted with a bispecific antibody with affinity for the tumorassociated antigen and for a hapten. After the tumor has been pretargeted with the bispecific antibody, the radiolabeled peptide conjugated with the hapten is injected. In a few pretargeting studies in mouse models, peptides labeled with positron-emitting radionuclides $\left({ }^{124} \mathrm{I},{ }^{68} \mathrm{Ga}\right.$, or $\left.{ }^{18} \mathrm{~F}\right)$ were used (15-17). These studies showed that with pretargeted immuno-PET, highcontrast images can be obtained that could be more sensitive and specific than ${ }^{18}$ F-FDG PET images. Pretargeted immuno-PET will soon be tested in cancer patients.

In conclusion, immuno-PET is a new technology that caused a revival of antibody imaging in cancer patients and can be applied for tailored patient management, dose calculation in radioimmunotherapy, and development of antibody-based drugs.

\section{ACKNOWLEDGMENT}

No potential conflict of interest relevant to this article was reported.
Otto C. Boerman
Wim J.G. Oyen
Radboud University Nijmegen
Medical Center
Nijmegen, The Netherlands

\section{REFERENCES}

1. Mach JP, Carrel S, Merenda C, Sordat B, Cerottini JC. In vivo localisation of radiolabelled antibodies to carcinoembryonic antigen in human colon carcinoma grafted into nude mice. Nature. 1974;248:704-706.

2. Goldenberg DM, DeLand F, Kim E, et al. Use of radiolabeled antibodies to carcinoembryonic antigen for the detection and localization of diverse cancers by external photoscanning. N Engl J Med. 1978; 298:1384-1386.

3. Carrasquilo JA, Pandit-Taskar N, O'Donoghuye JA, et al. ${ }^{124} \mathrm{I}$-huA33 antibody PET of colorectal cancer. J Nucl Med. 2011;52:1173-1180.

4. Chong G, Lee F, Hopkins W, et al. Phase I trial of ${ }^{131}$ I-huA33 in patients with advanced colorectal carcinoma. Clin Cancer Res. 2005;11:4818-4826.

5. Scott AM, Lee FT, Jones R, et al. A phase I trial of humanized monoclonal antibody A33 in patients with colorectal carcinoma: biodistribution, pharmacokinetics, and quantitative tumor uptake. Clin Cancer Res. 2005;11:4810-4817.

6. Divgi CR, Pandit-Taskar N, Jungbluth AA, et al. Preoperative characterisation of clear-cell renal carcinoma using iodine-124-labelled antibody chimeric G250 ( $\left.{ }^{124} \mathrm{I}-\mathrm{cG} 250\right)$ and PET in patients with renal masses: a phase I trial. Lancet Oncol. 2007;8:304-310.

7. Pre-surgical detection of clear cell renal cell carcinoma using radiolabeled G250-antibody. ClinicalTrials.gov Web site. Available at: www.clinicaltrials. gov/ct2/show/NCT00606632. Published January 21, 2008. Updated September 10, 2009. Accessed June 8, 2011.

8. Phase III registration trial: REDECT. Wilex Web site. Available at: www.wilex.de/R\&D/Redectane PhaseIII.htm. Accessed June 8, 2011.

9. Perk LR, Visser OJ, Stigter-van Walsum M, et al. Preparation and evaluation of ${ }^{89} \mathrm{Zr}$-Zevalin for monitoring of ${ }^{90} \mathrm{Y}$-Zevalin biodistribution with positron emission tomography. Eur J Nucl Med Mol Imaging. 2006;33:1337-1345.

10. Perk LR, Visser GW, Vosjan MJ, et al. ${ }^{89} \mathrm{Zr}$ as a PET surrogate radioisotope for scouting biodistribution of the therapeutic radiometals ${ }^{90} \mathrm{Y}$ and ${ }^{177} \mathrm{Lu}$ in tumorbearing nude mice after coupling to the internalizing antibody cetuximab. J Nucl Med. 2005;46:1898-1906.

11. Dijkers EC, Oude Munnink TH, Kosterink JG, et al. Biodistribution of ${ }^{89} \mathrm{Zr}$-trastuzumab and PET imaging of HER2-positive lesions in patients with metastatic breast cancer. Clin Pharmacol Ther. 2010;87:586-592.

12. Olafsen T, Wu AM. Antibody vectors for imaging. Semin Nucl Med. 2010;40:167-181.

13. Ahlgren S, Tolmachev V. Radionuclide molecular imaging using Affibody molecules. Curr Pharm Biotechnol. 2010;11:581-589.

14. Baum RP, Prasad V, Müller D, et al. Molecular imaging of HER2-expressing malignant tumors in breast cancer patients using synthetic ${ }^{111} \mathrm{In}$ - or ${ }^{68} \mathrm{Ga}$-labeled Affibody molecules. J Nucl Med. 2010;51:892-897.

15. McBride WJ, Zanzonico P, Sharkey RM, et al. Bispecific antibody pretargeting PET (immunoPET) with an ${ }^{124}$ I-labeled hapten-peptide. $\mathrm{J} \mathrm{Nucl} \mathrm{Med}$. 2006;47:1678-1688.

16. Sharkey RM, Karacay H, Vallabhajosula S, et al. Metastatic human colonic carcinoma: molecular imaging with pretargeted SPECT and PET in a mouse model. Radiology. 2008;246:497-507.

17. Schoffelen R, Sharkey RM, Goldenberg DM, et al. Pretargeted immuno-positron emission tomography imaging of carcinoembryonic antigen-expressing tumors with a bispecific antibody and a ${ }^{68} \mathrm{Ga}$ - and ${ }^{18} \mathrm{~F}$-labeled hapten peptide in mice with human tumor xenografts. Mol Cancer Ther. 2010;9:1019-1027. 